\title{
Ocelot (Leopardus pardalis) potential predation on a gray fox (Uro- cyon cinereoargenteus)
}

\section{Depredación potencial de zorra gris (Urocyon cinereoargenteus) por parte de un ocelote (Leopardus pardalis)}

\author{
Mircea G. Hidalgo-Mihart ${ }^{1,2 *}$, Alejandro Jesús-de la Cruz², and Rugieri Juárez-López ${ }^{1}$ \\ ${ }^{1}$ División Académica de Ciencias Biológicas, Universidad Juárez Autónoma de Tabasco, km 0.5 carretera Villahermosa-Cárdenas, \\ CP. 86040, Villahermosa, Tabasco, México. E-mail: mhidalgo@yahoo.com (MGH-M), ecolrugieri@hotmail.com (RJ-L). \\ ${ }_{2}^{2}$ Panthera México, Recreo 48, Col. Centro, CP. 37700, San Miguel de Allende, Guanajuato, México. E-mail: alexjc05@hotmail.com \\ (AJ-C). \\ * Corresponding author
}

\begin{abstract}
Gray fox (Urocyon cinereoargenteus) are commonly killed by other carnivores which can cause local population reductions. In tropical forests, the potential predators of gray fox are mostly large and medium sized felids. As part of a biodiversity survey using camera traps in the Yucatán Peninsula, we recorded an ocelot (Leopardus pardalis) carrying a gray fox in its mouth. Although we did not find evidence that the ocelot effectively predated the gray fox, the fact that was carried by the ocelot, potentially indicates the predation event. If this predation event is confirmed, this is the first time that a gray fox has been recorded being predated by an ocelot. Given that gray fox is the most abundant carnivore in the region, current reduction in ocelot populations due to human disturbances could have important effects on the species, such as an increase in their population size due to the reduction in predatory pressure.
\end{abstract}

Key words: Balam Ku; Calakmul; Campeche; diet; intraguild predation.

La zorra gris (Urocyon cinereoargenteus) es comúnmente depredado por otros carnívoros lo cual tiene como consecuencia reducciones locales en sus poblaciones. En los bosques tropicales, los depredadores potenciales de la zorra gris son en su mayoría felinos medianos y grandes. Como parte de un trabajo para determinar densidad de grandes felinos en la península de Yucatán, obtuvimos en una cámara trampa una fotografía en la que un ocelote (Leopardus pardalis) lleva en su boca una zorra gris. No encontramos evidencia de que la zorra gris fuera efectivamente depredada por el ocelote, pero el hecho de que el ocelote lleve en su boca a la zorra gris indica que potencialmente pudo existir el evento de depredación. De confirmarse este evento, sería la primera vez que se registra la depredación de una zorra gris por un ocelote. La zorra gris es el carnívoro más abundante de la región. La reducción actual en las poblaciones de ocelotes debido a disturbios humanos en la Península de Yucatán podría tener efectos importantes en especies como la zorra gris al favorecer el aumento de la población de esta especie ante la reducción de la depredación.

Palabras clave: Balam Ku, Calakmul; Campeche; dieta; depredación.

C 2020 Asociación Mexicana de Mastozoología, www.mastozoologiamexicana.org

The gray fox (Urocyon cinereoargenteus) is a medium sized canid that is widely distributed from southern Canada to northern South America. In the United States, their major source of mortality is human related (Cypher 2003), but the gray fox is also commonly killed by other carnivores, raptors (Cypher 2003; Farias et al. 2005) or by disease (e.g., distemper; Nicholson and Hill 1984), which can cause local population reductions. The most important gray fox predator is the coyote (Canis latrans); which usually only kills them but does not consume the meat (Farias et al. 2005), a process known as interspecific killing (i.e., the killing of potentially competing species without any immediate energetic gain to the predator species; Polis et al. 1989). However, in areas where coyotes are inexistent or uncommon, such as the tropical forests of southeastern México and the Yucatán Peninsula, Central America and northern South America (Hidalgo-Mihart et al. 2004), the potential predators of the gray fox are the jaguar (Panthera onca), puma (Puma concolor) and the ocelot (Leopardus pardalis; De Oliveira and Pereira 2014).
Diet analyses have observed that pumas and jaguars occasionally feed on gray fox (Monroy-Vilchis et al. 2009; Ávila-Nájera et al. 2018). In the case of ocelots, although their food habits have been extensively studied in areas where ocelots and gray foxes are sympatric (e.g., De VillaMeza et al. 2002; Booth-Binczik et al. 2013; Gómez-Ortíz et al. $\underline{2015}$ ), gray fox remains have only been recorded in one ocelot scat in Belize (Mesa-Cruz et al. 2016). It is not possible to determine if this Belize gray fox was predated or scavenged. Ocelots scavenging behavior on road killed foxes (Crab eating fox; Cerdocyon thous) was commonly observed in Brazil (Crawshaw 1995), indicating that scavenging on fox species by ocelots it is an usual behavior for this species, supporting the possibility that the presence of gray fox remains in a scat in Belize could be due to scavenging. In this note, we describe for the first time a likely predation event of an ocelot on a gray fox obtained in a series of pictures from a camera trap in the Balam-Ku State Reserve, Campeche.

As part of a study aimed to determine the jaguar density in the Calakmul and Balam-Ku area in the south of the 
Yucatán Peninsula, we installed a network of 69 camera trap stations separated for at least $2 \mathrm{~km}$ from each other, in an approximate area of $500 \mathrm{~km}^{2}$. The area was located in the western part of the Calakmul Region in Campeche, a landscape of low hills that varies from 50-150 m. Climate in the region is warm (mean temperature during the year 26-28 ${ }^{\circ} \mathrm{C}$ ) with precipitation ranging from $1000-1500 \mathrm{~mm} \mathrm{y}^{-1}$ that occurs mostly during a five months rainy season (June to October; Instituto Nacional de Estadistica y Geografía 2015). The vegetation of the area is mostly composed by preserved tropical semideciduous forest (Rzedowski 2006) but selective logging in the region is common and has impacted the forest's species composition. We set 45 single and 24 double camera trap stations (Pantheracam Model IV or V) that were active during the rainy season from early July to the first part of October of 2018. We set the traps along pathways, firebreaks and roads in the region, tied to trees at a height of 50 $\mathrm{cm}$ and programmed to function $24 \mathrm{~h}$ a day.

On August 4, 2018 at 00:35, we obtained a picture of a male ocelot carrying a gray fox (Figure 1c). The camera was located on a dirt road inside a preserved area of the Balam Ku State Reserve (UTM 15N 804377, 2019223). In the image, the ocelot appears to be moving from right to left with the gray fox in its mouth. This picture was preceded by two photographs of the same ocelot (identified by the individual coat spotted pattern observed in this single camera trap station, and in a double camera trap neighborhood station; Di Bitetti et al. 2006) at 00:23; 00:32, without the gray fox (Figure 1a-b). The feline was identified as an ocelot because it is a medium sized spotted cat with a tail that is not bushy and shorter than the length of the hind legs (Reid 2009). The only medium-sized spotted cat that can be confused in the study area is the margay L. wiedii, but the ocelot is larger and heavier than that species, and the margay has a bushy tail that is longer than the hind legs (Reid 2009). The canid was identified as a gray fox because of the small and slim body and the mostly grayish fur with rusty ears, legs and chest, as well as the bushy tail. Also, the gray fox is the only canid of this size distributed along the study area (Reid 2009). We found no evidence of the ocelot consuming the gray fox in pictures nor did we find remains around the camera trap. It has been observed that when bobcats (a felid with similar size than the ocelot) killed gray foxes, the gray fox is at least partially consumed (Farias et al. $\underline{2005}$ ), contrary to what occurs when gray foxes are killed by coyotes in interspecific killing events. This suggests that even we did not found evidences of the ocelot consuming the gray fox, it is highly possible that the gray fox was consumed outside of the camera trap vision area.

Ocelot diets are mainly comprised of small mammals, but also include medium to large mammals, reptiles, amphibians, birds and fishes (De Villa-Meza et al. 2002; Booth-Binczik et al. 2013; Gómez-Ortíz et al. 2015). Other carnivore species (e.g., coati Nasua narica, racoon Procyon lotor and tayra Eira barbara) have also been reported in ocelot's diet although not commonly (see De Oliveira and
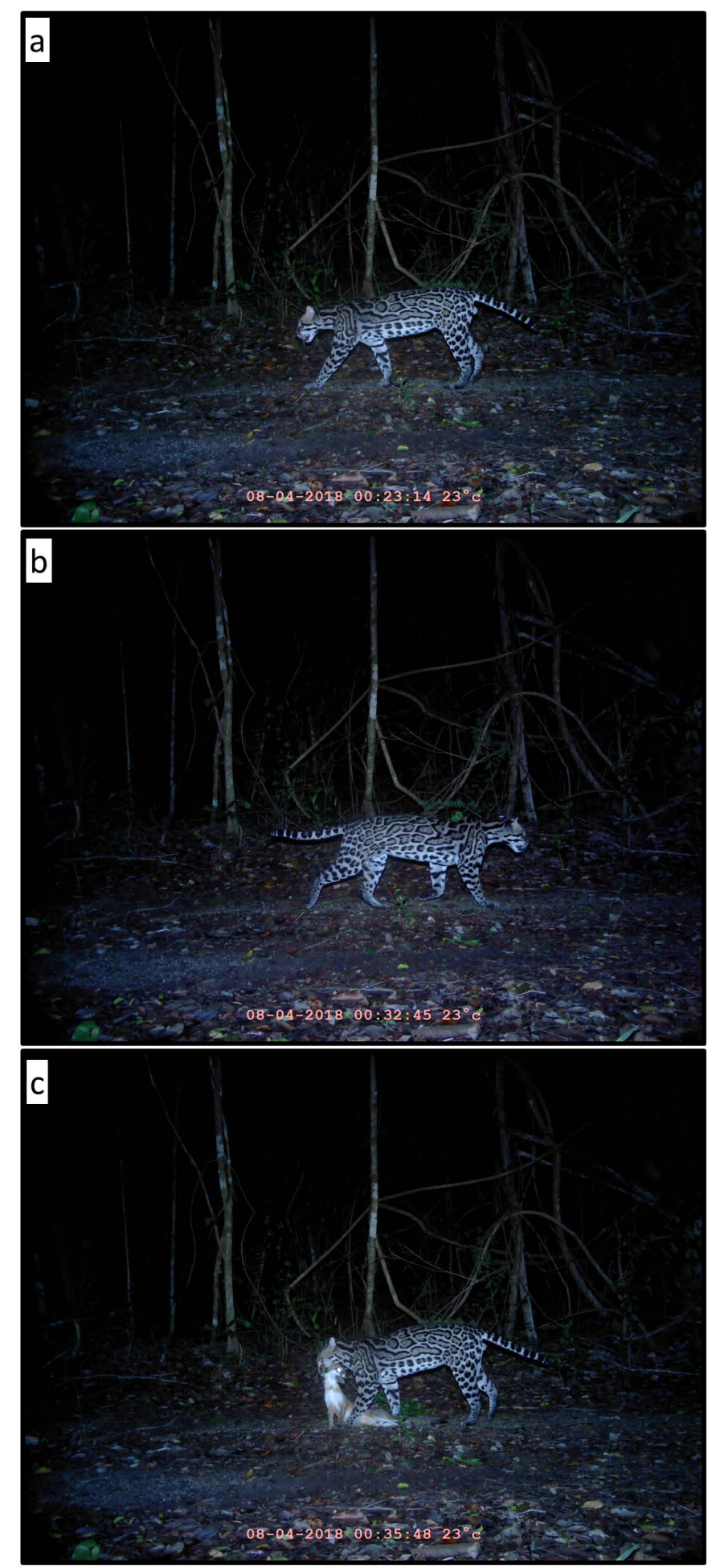

Figure 1. a) and b) Pictures of male ocelot (Leopardus pardalis) roaming in front of a camera trap obtained at the Balam Ku State Reserve, in the Yucatán Peninsula, México. c) Picture of the male ocelot carrying a gray fox (Urocyon cinereoargenteus).

Pereira 2014 for a review). With the exception of the Belize diet analysis, where gray fox remains were observed in an ocelot scat (Mesa-Cruz et al. 2016), there are no other reports of ocelots feeding on gray foxes.

Currently, in the Yucatán Peninsula the gray fox is one of the most common and abundant carnivores (Urquiza-Haas et al. 2009; Ávila-Nájera et al. 2018). Even though this is the first time that a gray fox has been recorded being poten- 
tially predated by an ocelot, due to the abundance of this canid in the Yucatán Peninsula it is possible that ocelots and gray foxes commonly interact, and these predation events occur frequently. To determine the importance of this canid in the ocelot's diet, it is necessary to increase our knowledge of ocelot diet in the region.

The removal of larger predators has resulted in the increase in the numbers of gray fox, suggesting that predation limits some fox populations (Crooks and Soule 1999; Henke and Bryant 1999). Jaguars, pumas, and ocelots are the species most likely to have an impact on the structure of the Neotropical carnivoran guild. Of these three species, it is likely that the medium-sized ocelots exert the greatest impact as they attain higher population densities (De Oliveira and Pereira 2014). Current reduction in felid populations and specially ocelots due to the increase in human densities and consequent pressure in the Yucatán Peninsula (UrquizaHaas et al. 2009) could have important effects on their prey, especially species like the gray fox that are already abundant in the area and could be more susceptible to an increase in population size if there is a reduction in predation.

\section{Acknowledgements}

This study was performed with support from the Comisión Nacional de Áreas Naturales Protegidas (CONANP) through the Project PROCER 2018 "10.8 Seguimiento de los esfuerzos de los censos de jaguar en México". We are grateful to the authorities and inhabitants of the Ejido Silvituc, Campeche for allowing us to carry out this study on their land. We thank the Secretaría del Medio Ambiente y Recursos Naturales del Estado de Campeche (SEMARNATCam) for the continuous support for the project, especially to J. López-Sosa, E. Uc-Manrrero and E. Juárez-Mendoza. We thank the División Académica de Ciencias Biológicas of the Universidad Juárez Autónoma de Tabasco (DACBiolUJAT), Panthera México A.C. and Conservación de Vida Silvestre y Desarrollo Comunitario COVIDEC A. C. for logistical support. We thank D. Friedeberg for their suggestions to improve the manuscript.

\section{Literature cited}

Ávila-Nájera, D. M., F. Palomares, C. Chávez, B. Tigar, and G. D. Mendoza. 2018. Jaguar (Panthera onca) and puma (Puma concolor) diets in Quintana Roo, Mexico. Animal Biodiversity and Conservation 41:257-266.

Booth-Binczik, S. D., R. D. Bradley, C. W. Thompson, L. C. Bender, J. W. Huntley, J. A. Harvey, L. L LaAck, and J. L. Mays. 2013. Food habits of ocelots and potential for competition with bobcats in southern Texas. The Southwestern Naturalist 58:403-411.

CRawshaw, P. G. JR. 1995. Comparative ecology of ocelot Felis pardalis and jaguar Panthera onca in a protected subtropical forest in Brazil and Argentina. PhD Dissertation, University of Florida. Gainesville, U.S.A.

CRooks, K. R., AND M. E. Soule. 1999. Mesopredator release and avifaunal extinctions in a fragmented system. Nature (London) 400:563-566.
Cypher, B. L. 2003. Foxes - Vulpes species, Urocyon species, and Alopex lagopus. Pp. 511-546 in Wild mammals of North America: biology, management, and conservation. Second edition (Feldhamer G. A., B. C. Thompson, and J. A. Chapman, eds.). Johns Hopkins University Press. Baltimore, U.S.A.

De Oliveira, T. G., AND J. A. Pereira. 2014. Intraguild predation and interspecific killing as structuring forces of carnivoran communities in South America. Journal of Mammalian Evolution 21:427-436.

De Villa-Meza, A., E. Martínez-Meyer, and C. A. López-González. 2002. Ocelot (Leopardus pardalis) food habits in a tropical deciduous forest of Jalisco, México. American Midland Naturalist 148:146-154.

Di Bitetti, M. S., A. Paviolo, and C. de Angelo. 2006. Density, habitat use and activity patterns of ocelots (Leopardus pardalis) in the Atlantic Forest of Misiones, Argentina. Journal of Zoology 270:153-163.

Farias, V., T. K. Fuller, R. K. Wayne, and R. M. Sauvajot. 2005. Survival and cause-specific mortality of gray foxes (Urocyon cinereoargenteus) in southern California. Journal of Zoology 266:249-254.

Gómez-Ortiz, Y., O. Monroy-Vilchis, and G. D. Mendoza-Martínez. 2015. Feeding interactions in an assemblage of terrestrial carnivores in central Mexico. Zoological Studies 54:1-16.

Henke, S. E., and F. C. Bryant. 1999. Effects of coyote removal on the faunal community in western Texas. Journal of Wildlife Management 63:1066-1081.

Hidalgo-Mihart, M. G., L. Cantú-Salazar, A. González-Romero, and C. A López-González. 2004. Historical and present distribution of coyote (Canis latrans) in Mexico and Central America. Journal of Biogeography 31:2025-2038.

Instituto Nacional de Estadística y Geografía. 2015. Anuario estadístico y geográfico de Campeche. Instituto Nacional de Estadística y Geografía y Gobierno del Estado de Campeche. Aguascalientes, México.

Mesa-Cruz, J. B., J. L. Brown, L. P. Waits, and M. J. Kelly. 2016. Non-invasive genetic sampling reveals diet shifts, but little difference in endoparasite richness and fecal glucocorticoids, in Belizean felids inside and outside protected areas. Journal of Tropical Ecology 32:226-239.

Monroy-Vilchis, O., Y. Gómez, M. Janczur, and V. Urios. 2009. Food niche of Puma concolor in central Mexico. Wildlife Biology 15:97-105.

NicHOLSON, W. S., AND E.P. HILL. 1984. Mortality in gray foxes from eastcentral Alabama. Journal of Wildlife Management 48:429-1432.

Polis, G. A., C. A. Myers, ANd R. D. Holt. 1989. The ecology and evolution of intraguild predation: Potential competitors that eat each other. Annual Review of Ecology and Systematics 20:297-330.

ReID, F. 2009. A field guide to the mammals of Central America and Southeast Mexico. Second edition. Oxford University Press. New York, U.S.A.

Rzedowskı, J. 2006. Vegetación de México. Comisión Nacional para el Conocimiento y Uso de la Biodiversidad. Ciudad de México, México.

Urquiza-HaAs, T., C. A. Peres, C. A., and P. M. Dolman. 2009. Regional scale effects of human density and forest disturbance on large-bodied vertebrates throughout the Yucatán Peninsula, Mexico. Biological Conservation 142:134-148. 
Associated editor: Beatriz Bolívar

Submitted: December 18, 2019; Reviewed: March 9, 2020.

Accepted: March 27, 2020; Published on line: April 4, 2020. 